\title{
New sulfur-phosphine ligands derived from sugars: synthesis and application in palladium-catalyzed allylic alkylation and in rhodium asymmetric hydrogenation
}

\author{
Noureddine Khiar, ${ }^{\mathrm{a} *}$ Raquel Navas, ${ }^{\mathrm{a}}$ Eleuterio Álvarez, ${ }^{\mathrm{a}}$ and Inmaculada Fernández ${ }^{\mathrm{b} *}$ \\ ${ }^{a}$ Instituto de Investigaciones Químicas, C.S.I.C-Universidad de Sevilla, c/. Américo Vespucio, \\ s/n., Isla de la Cartuja, 41092 Sevilla, Spain \\ ${ }^{b}$ Departamento de Química Orgánica y Farmacéutica, Facultad de Farmacia, Universidad de \\ Sevilla, c/ Profesor García González, 2, 41012 Sevilla, Spain \\ E-mail: khiar@iiq.csic.es
}

\section{Dedicated to Professor Arlette Solladié-Cavallo on her $\mathbf{7 0}^{\text {th }}$ birthday}

\begin{abstract}
An efficient route to mixed phosphine / thioglycoside ligands type IV starting from glucose pentaacetate is reported. In only five steps the key epoxide 6 has been obtained in high yield and its structure determined by X-ray analysis. The ring opening of the tert-butyl 4,6-O-benzylidene2,3-anhydro-1-thio- $\beta$-D-allopyranoside 6 with diphenylphosphinyl lithium afforded the desired ligand as a single diastereoisomer. The prepared compounds act as a bidentate ligands as shown by X-ray analysis of the $\mathrm{Rh}(\mathrm{I})$-complex 12. Preliminary results on the behaviour of these ligands in $\operatorname{Pd}(0)$-catalyzed allylic alkylation, and in $\mathrm{Rh}(\mathrm{I})$-catalyzed enamide hydrogenation are also reported.
\end{abstract}

Keywords: S-P Ligands, carbohydrates, Pd-catalyzed allylic alkylation, asymmetric hydrogenation

\section{Introduction}

The significance of optically pure compounds in important areas such as agriculture, fragance, and medicine is actually well recognized. As illustrative data, more than $50 \%$ of the drugs currently in the market are enantiopure compounds, and the main biologically significant molecules needed for basic biomedical studies, possess at least one chiral centre. ${ }^{1}$ Consequently, the design of new and efficient processes allowing the synthesis of chiral compounds with high optical purities represent an important goal for academic and industrial synthetic chemists. ${ }^{2}$ Among all the different ways to ensure chiral transition state, enantioselective catalysis is the 
method of choice, as it combines both efficiency and versatility. ${ }^{3}$ Enantioselective catalysis is usually achieved by using a transition metal bound to a chiral organic ligand, responsible for the enantiodiscrimination. Surprisingly, an analysis of the massive literature on metal catalyzed asymmetric synthesis shows that most of the ligands developed so far, are based on discrete chiral framework. ${ }^{4}$ On the other hand, despite the enormous and continuous efforts devoted to this area in the last three decades, its impact in the arena of fine chemicals synthesis is still reduced. ${ }^{5}$ One of the main reasons for this situation is that the catalyst precursors are generally relatively expensive complex molecules obtained through multisteps synthesis. Carbohydrates, which are amongst the cheapest and abundant chiral starting materials, hold a range of structural characteristics making them very appealing for such venture. ${ }^{6}$ In a project directed toward the use of chiral sulfur compounds in asymmetric synthesis, ${ }^{7}$ we have recently started a research program directed toward the use of sulfur based ligands derived from carbohydrates and their applications in enantioselective catalysis. ${ }^{8}$ Although, we have found that $\mathrm{C}_{2}$-symmetric bisthioglycosides $\mathbf{I}^{8 \mathrm{a}, \mathrm{c}}$ and $\mathrm{C}_{1}$-symmetric thioglycosides $\mathbf{I I}^{8 \mathrm{~d}}$ (Figure 1), are good ligands for palladium catalyzed allylic alkylation, the catalyst derived from mixed S/P ligand III exhibited both improved reactivity and enantioselectivity. ${ }^{8 \mathrm{~b}}$ In order to evaluate the contribution of the phosphinite moiety, and the ring size in the metallacycle intermediate to the catalytic behavior of III, a related ligand with a phosphine directly linked to the C-2 carbon instead of a phosphinite was needed. In the present work, we report on the first synthesis of bidentated S/P ligand IV, derived from glucose, the characterization of its rhodium complex and the preliminary applications in $\mathrm{Rh}(\mathrm{I})$-catalyzed enamide hydrogenation and palladium-(0)-catalyzed allylic substitution.
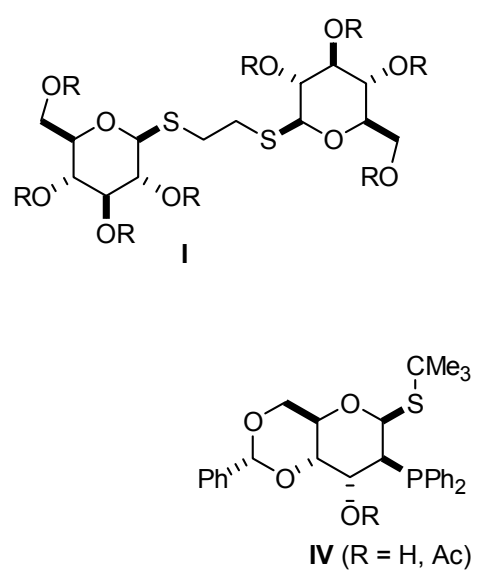
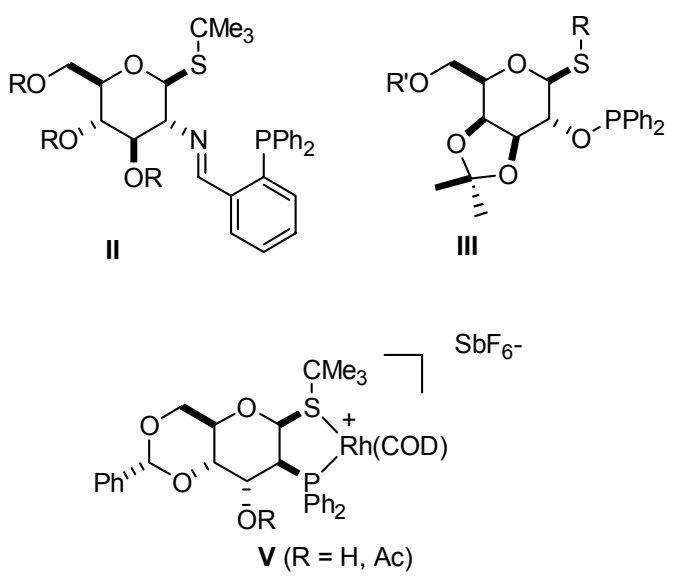

\section{Figure 1}




\section{Results and Discussion}

One of the most salient features of thioether based ligands is that upon coordination to the metal, the sulfur atom becomes stereogenic. ${ }^{8,9}$ Consequently, high enantioselectivities are expected with these ligands, ${ }^{10}$ as far as the low inversion barrier of the sulfur metal bond can be restricted. ${ }^{11}$ Thus any attempt to use sulfur based ligands must contemplate the stereocontrol of the sulfur metal bond, either through steric or stereoelectronic bias. ${ }^{12}$ In the case of S/P ligands reported in this work a tert-butyl group has been attached to the sulfur atom in order to favor one diastereomeric metal complex as a consequence of steric interactions between this group and the pyranose ring. ${ }^{8 b}$ While there is a large number of sugar based ligands with a phosphorus atom, the main type deals with a phosphorus atom attached to oxygen as a phosphinite and phosphite group. ${ }^{13}$ Ligands with phosphorus directly attached to a carbon atom of the pyranose ring are scarce, as a consequence of the synthetic difficulty for their preparation. Taking into account the large amount of elimination which takes place in the nucleophilic substitution with anions for the preparation of 2-deoxy-sugars, the best strategy followed so far, is the ring opening of epoxides. ${ }^{14}$ Nevertheless, in view of the absence of precedents on the synthesis of 2,3-anhydro-1deoxy- $\beta$-thioglycoside, a modular synthetic approximation was first developed (Scheme 1$)$. The first step is a thioglycosylation using the sterically hindered tert-butanethiol as glycosyl acceptor, glucose pentaacetate $\mathbf{1}$ as glycosyl donor, and $\mathrm{BF}_{3} \mathrm{Et}_{2} \mathrm{O}$ as activator. We have recently found that this transformation is under thermodynamic control, being the $\alpha$-thioglycoside the more stable isomer. ${ }^{8 \mathrm{~b}}$ In order to obtain the kinetic isomer, the reaction was conducted at $0{ }^{\circ} \mathrm{C}$ affording the desired product $\mathbf{2}$ in $70 \%$ yield as a white solid.

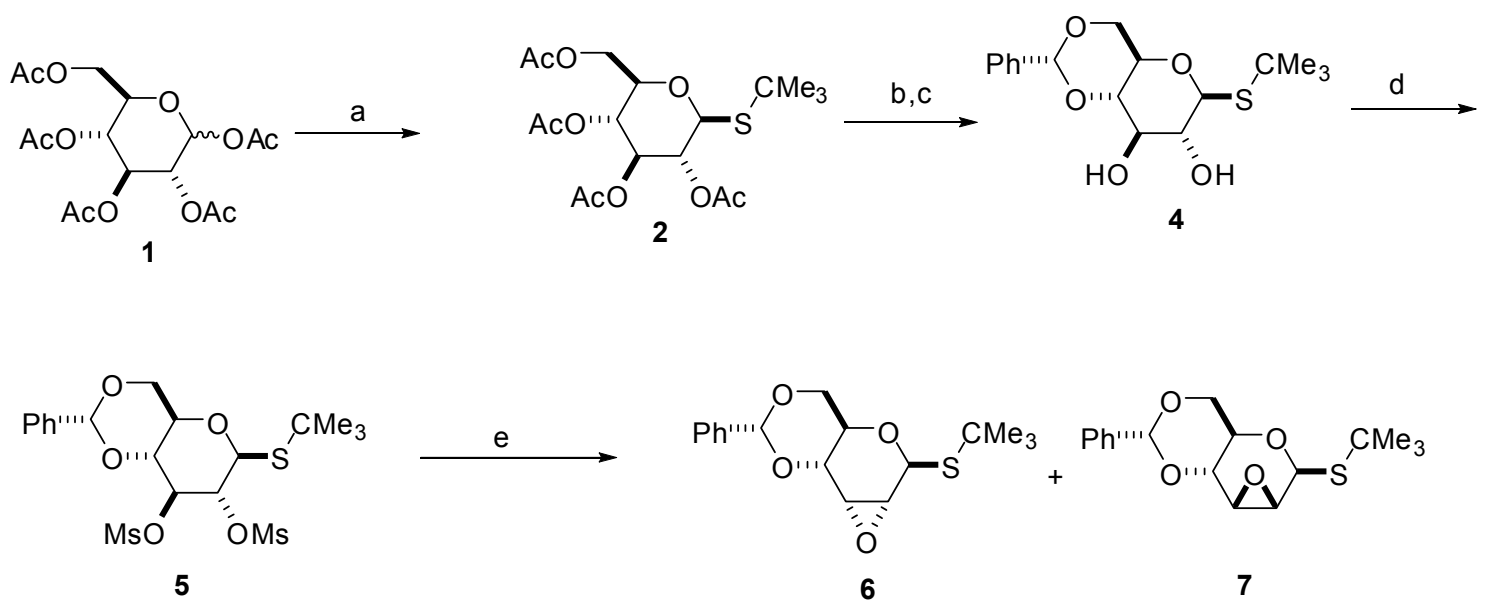

Scheme 1. (a) $t$ - $\mathrm{BuSH}, \mathrm{CH}_{2} \mathrm{Cl}_{2}, \mathrm{BF}_{3} \mathrm{Et}_{2} \mathrm{O}, 0^{\circ} \mathrm{C}, 70 \%$; (b) $\mathrm{MeONa}, \mathrm{MeOH}$, quant; (c) $\mathrm{PhCH}(\mathrm{OMe})_{2}, p$ - $\mathrm{TsOH}, \mathrm{DMF}, 50^{\circ} \mathrm{C}, 90 \%$; (d) $\mathrm{MsCl}$, pyridine, $0^{\circ} \mathrm{C}-\mathrm{rt}, 90 \%$; (e) $\mathrm{MeONa}$, $\mathrm{CH}_{2} \mathrm{Cl}_{2} / \mathrm{H}_{2} \mathrm{O}, 75 \%$. 
A Zemplen deacetylation followed by acid catalyzed benzylidene acetal formation in DMF afforded diol $\mathbf{4}$ in 90\% yield. The double protection of 3,4-diol afforded the dimesylate 5 which, upon treatment with sodium methoxide, afforded the two possible allo- and manoepoxides $\mathbf{6}$ and 7 in a $3: 2$ ratio. Eventhough the two epoxides have a good separation factor, which allows their purification, the unequivocal determination of their structures could not be done by NMR analysis. Fortunately, we could obtain a single crystal of the major epoxide 6, suitable for X-ray crystallographic analysis, and its structure is given in Figure $2 .{ }^{15}$

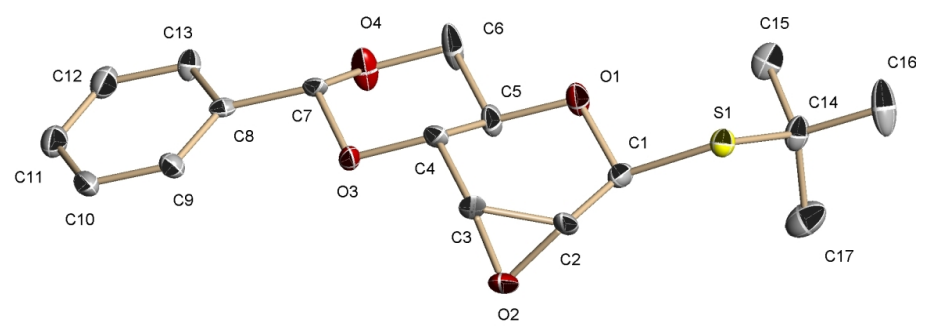

Figure 2. ORTEP drawing of epoxide 6.

As it can be seen from Figure 2, the major compound $\mathbf{6}$ is the allo epoxide with a $(2 R, 3 R)$ absolute configuration in the oxirane ring. The compound crystallizes in a ${ }^{0} \mathrm{H}_{5}$ (D) half chair conformation with the bulky tert-butylsulfenyl group in a pseudo equatorial position. The NMR data of compound $\mathbf{6}$ are in complete agreement with the crystalline structure indicating that in solution the allo epoxide adopts also the ${ }^{\mathrm{O}} \mathrm{H}_{5}$ (D) half chair conformation. Once determined that the major and minor epoxides $\mathbf{6}$ and 7, correspond to the allo- and mano-epoxides respectively, the key opening oxirane step was studied.
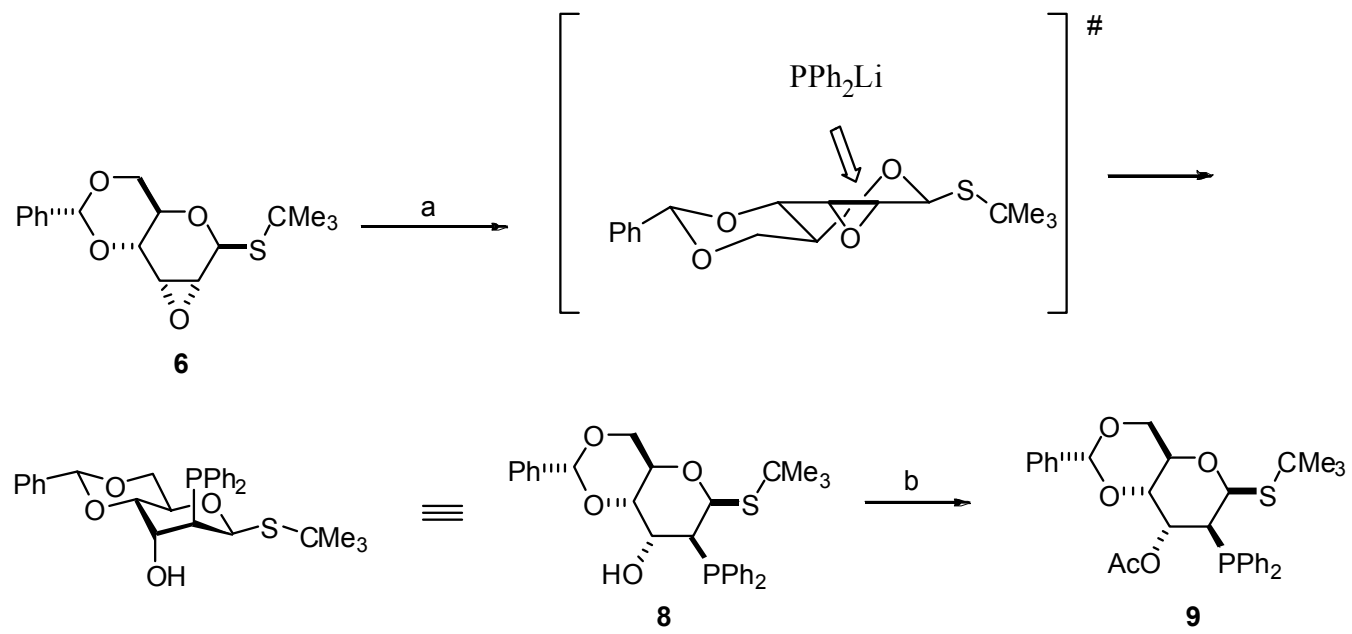

Scheme 2. (a) $\mathrm{PPh}_{2} \mathrm{Li}_{1} \mathrm{Et}_{2} \mathrm{O} / \mathrm{DMF},-10{ }^{\circ} \mathrm{C}, 78 \%$; (b) $\mathrm{Ac}_{2} \mathrm{O}$, Pyridine, $82 \%$. 
Addition of freshly prepared diphenylphosphinyl lithium $\left(\mathrm{PPh}_{2} \mathrm{H}+\mathrm{BuLi}\right)$ on a solution of epoxide 6 disolved in a deoxygenated $\mathrm{Et}_{2} \mathrm{O}$ :DMF (1:1) mixture, afforded the desired phosphine 8 as a single diastereoisomer. Homo- and heteronuclear NMR analyses indicate that the opening of the epoxide takes place as predicted at the 2 position in accord with the Fürst-Plattner rule (1,2trans diaxial opening). ${ }^{16}$ Treatment of compound 8 with acetic anhydride in pyridine afforded the fully protected mixed $\mathrm{S} / \mathrm{P}$ ligand $\mathbf{9}$.

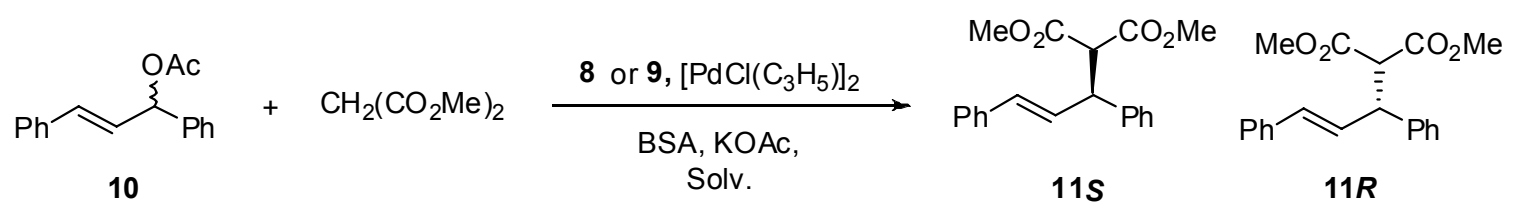

\section{Scheme 3}

The ability of the prepared phosphine thioglycosides 8 and 9 to act as chiral ligands in asymmetric catalysis was first assayed in the model reaction of palladium catalyzed allylic alkylation of 1,3-diphenylpropenyl acetate $\mathbf{1 0}$ with dimethyl malonate, ${ }^{17}$ Scheme 3 , and the results are given in Table 1.

As it can be seen from Table 1, in the particular case of ligand $\mathbf{8}$, beside the modest chemical yield, the enantioselectivity was also deceiving as the allylated product was obtained in racemic form (Table 1, entry 1).

Table 1. Pd-Catalyzed allylic alkylation of 1,3-diphenylpropenyl acetate $\mathbf{1 0}$ with dimethyl malonate using S/P ligands 8 or $\mathbf{9}^{\mathrm{a}}$

\begin{tabular}{ccccc}
\hline Entry & Solv. & Ligand & Yield $(\%)^{\mathrm{b}}$ & $\begin{array}{c}\text { Enantiomeric ratio } \\
(11 R / 11 S)^{\mathrm{c}, \mathrm{d}}\end{array}$ \\
\hline 1 & $\mathrm{CH}_{3} \mathrm{CN}$ & $\mathbf{8}$ & 24 & $50 / 50$ \\
2 & $\mathrm{CH}_{3} \mathrm{CN}$ & $\mathbf{9}$ & 64 & $60 / 40$ \\
3 & $\mathrm{CH}_{2} \mathrm{Cl}_{2}$ & 9 & 65 & $60 / 40$ \\
4 & $\mathrm{CH}_{2} \mathrm{Cl}_{2}$ & 9 & 55 & $65 / 35^{\mathrm{e}}$ \\
\hline
\end{tabular}

${ }^{\mathrm{a}} \mathrm{All}$ reactions were conducted using $4.3 \mathrm{~mol} \%$ of the ligand and $1.5 \mathrm{~mol} \%$ of $\left[\mathrm{PdCl}\left(\mathrm{C}_{3} \mathrm{H}_{5}\right)\right]_{2}$ at r.t. ${ }^{\mathrm{b}}$ Isolated yields. ${ }^{\mathrm{c}}$ Determined by HPLC using chiral column Chiralpack-AD. ${ }^{\mathrm{d}} R$ or $S$ configurations based on specific rotation. ${ }^{\mathrm{e}}$ Reaction conducted at $-15^{\circ} \mathrm{C}$.

The acetyl group at the 3 position of the ligand has a beneficial effect on the palladium catalyzed allylic alkylation as the ligand $\mathbf{9}$ affordded the product $\mathbf{1 1}$ with better chemical yield. 
Nevertheless, concerning the enantioselectivity the allylated product was obtained with a very low $20 \%$ ee in favor of the $R$ isomer. The change of the solvent from acetonitrile to methylene chloride did not improve the enantioselectivity, while lowering the temperature allowed the synthesis of $11 R$ in $30 \%$ enantiomeric excess and $55 \%$ chemical yield. It is worth mentioning that the enantioselectivity observed is far from the $96 \%$ ee obtained with the related phosphinite thioglycoside (Figure 1, ligand III, $\mathrm{R}=\mathrm{CMe}_{3}, \mathrm{R}^{\prime}=\mathrm{Ac}$ ) recently reported by us. ${ }^{8 \mathrm{~b}}$ These results may be rationalized by the different electronic effects of the phopshinite and phosphine moiety, together with a better ability of the six member palladacycle intermediate $\mathbf{A}$, compared to the five member palladacycle $\mathbf{B}$, to transfer the chiral information of the sugar to the $\pi$-allyl moiety, Figure 3.

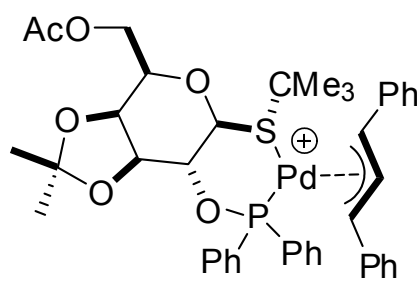

A

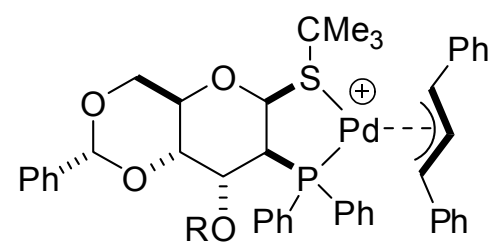

B

\section{Figure 3}

Next we evaluated the capacity of the prepared S/P ligands in the asymmetric synthesis of amino acids through the enantioselective hydrogenation of enamides. ${ }^{18}$ While there are a large number of effective chiral bis-phosphines for this transformation, ${ }^{19}$ the few mixed ligands used, usually lead to low reactivity or selectivity or both. To start this study we first synthesized a well defined Rh(I) catalyst precursor. Treatment of 1 equiv. of 9 with 1 equiv. of $\left[(\mathrm{COD})_{2} \mathrm{Rh} \mathrm{SbF}_{6}{ }^{20}\right.$ in methylene chloride afforded the cationic complex $\mathbf{1 2}$ in quantitative yield as an orange solid, Scheme 4.
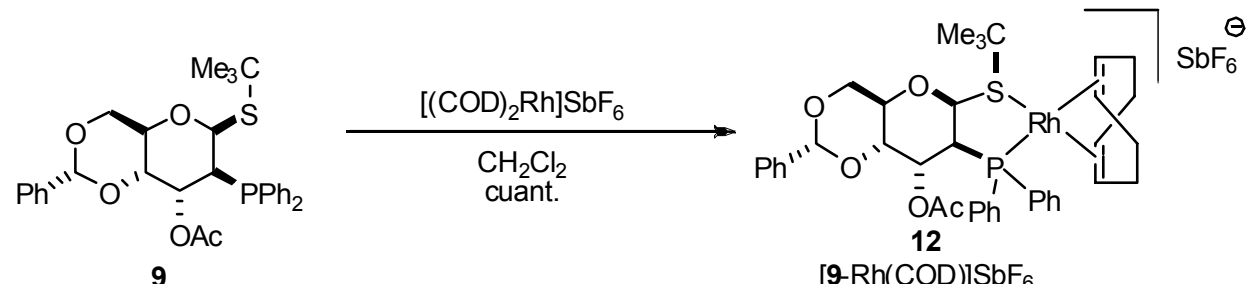

\section{Scheme 4}

As stated in the introduction one of the most important characteristic of mixed $\mathrm{S} / \mathrm{P}$ ligands is that upon coordination to the metal, the sulfur atom becomes stereogenic. Interestingly, ${ }^{1} \mathrm{H},{ }^{31} \mathrm{P}$, and ${ }^{13} \mathrm{C}$ NMR analyses indicate that complex $\mathbf{1 2}$ is formed as a single diatereoisomer. 
Furthermore, compound $\mathbf{1 2}$ is a crystalline compound, and we could get appropriate crystal for X-ray studies, Figure $4 .^{21}$

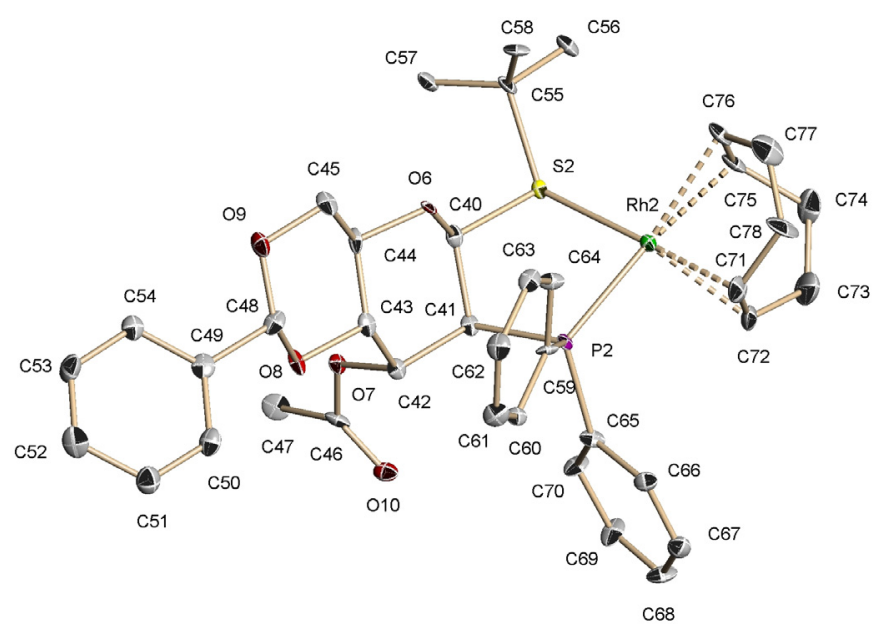

Figure 4. ORTEP drawing of compound $12[9 \mathrm{Rh}(\mathrm{COD})] \mathrm{SbF}_{6}\left(\mathrm{SbF}_{6}\right.$ removed for clarity).

As it can be seen from Figure 4, in the Rh(I) complex 12, compound 9 acts as a bidentate ligand, as the rhodium is coordinated to the phosphorus and the sulfur atoms, leading to a five member metalacycle. In complex $\mathbf{1 2}$, the sugar crystallizes under a ${ }^{4} \mathrm{C}_{1}$ conformation, while the 5 member metalacycle has an envelope conformation. Unexpectedly, the absolute configuration at sulfur is $R$, and the bulky tert-butyl group, in a pseudo equatorial position, is in an unfavorable gauche relationship with the endocyclic oxygen. ${ }^{22}$ This result may be explained taking into account that under the envelope conformation, a pseudo axial disposition of the tert-butyl group undergoes a severe steric interaction with the cyclooctadiene coligand. The geometry around the rhodium atom is square planar, slightly distorted with S-Rh-P angle of $84.49(8)^{\circ}$ typical of $\mathrm{Rh}(\mathrm{I})$ cationic complexes. Interestingly, the bond lengths trans to the phosphorus $[\mathrm{Rh}-\mathrm{C}(75)=2.264$ $\left.\mathrm{A}^{\mathrm{o}} \mathrm{y} \mathrm{Rh}-\mathrm{C}(76)=2.244 \mathrm{~A}^{\circ}\right]$ are about $0.1 \mathrm{~A}^{\circ}$ longer than those trans to the sulfur $[\mathrm{Rh}-\mathrm{C}(71)=$ $\left.2.149 \mathrm{~A}^{\mathrm{o}} \mathrm{y} \mathrm{Rh}-\mathrm{C}(72)=2.161 \mathrm{~A}^{\mathrm{o}}\right]$, indicative of the large trans influence of the phosphorus compared to the sulfur.

Once determined the structure of the precatalyst, it was used in the model reaction of hydrogenation of methylacetamido cinnamate 13, leading to the protected phenylalanine 14, Scheme 5, and the results are given in Table 2.

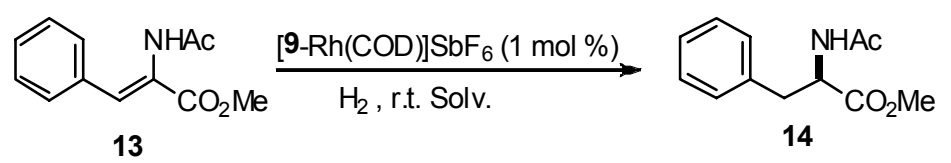

\section{Scheme 5}


Table 2. Hydrogenation of methyl acetamido cinnamate 13 using $\mathrm{Rh}(\mathrm{I})$-complex $12^{\mathrm{a}}$

\begin{tabular}{ccccc}
\hline Entry & Solv. & $\mathrm{P}(\mathrm{atm})$ & $\begin{array}{c}\text { Conversion } \\
(\%)^{\mathrm{b}}\end{array}$ & $\begin{array}{c}\text { Enantiomeric ratio } \\
(14 R / 14 S)^{\mathrm{c}}\end{array}$ \\
\hline 1 & $\mathrm{CH}_{2} \mathrm{Cl}_{2}$ & $\mathbf{4}$ & 0 & -- \\
$3^{\mathrm{d}}$ & $\mathrm{CH}_{2} \mathrm{Cl}_{2}$ & $\mathbf{2 0}$ & 12 & nd \\
4 & $\mathrm{CH}_{2} \mathrm{Cl}_{2}$ & $\mathbf{4 0}$ & 70 & $55 / 45$ \\
& $\mathrm{MeOH}$ & $\mathbf{4}$ & 0 & -- \\
\hline
\end{tabular}

${ }^{\mathrm{a}}$ All reactions were conducted using $1 \mathrm{~mol} \%$ of the complex 12. ${ }^{\mathrm{b}}$ Determined by ${ }^{1} \mathrm{H} \mathrm{NMR}$ analysis of the crude. ${ }^{\mathrm{c}}$ Determined by HPLC using chiral column Chiralcel OJ. ${ }^{\mathrm{d}}$ Reaction conducted with $5 \mathrm{~mol} \%$ of $\mathbf{1 2}$.

As it can be seen from Table 2 , the $\mathrm{Rh}(\mathrm{I})$ catalyst $\mathbf{1 2}$ was not very active in the hydrogenation of methylacetamido cinnamate $\mathbf{1 3}$, as up to 40 atm. were necessary to afford only a $70 \%$ conversion to the phenylalanine derivative 14. With regard to the enantioselectivity, the product was obtained with a very low $10 \%$ ee in favor of the $R$ isomer. These results which are in accord with those obtained in the Pd-catalyzed allylic alkylation, indicate that phosphine thioglycoside I are not suitable ligands for processes catalyzed by square planar $\mathrm{d}^{8}$ metals.

In conclusion, we have reported a simple, modular and efficient synthetic approach for the synthesis of new mixed S/P ligands, using carbohydrates as cheap starting materials. The strategy is based on the diastereoselective opening of the tert-butyl 4,6-O-benzylidene-2,3anhydro-1-thio- $\beta$-D-allopyranoside with diphenylphosphinyl lithium. The obtained compounds act as a bidentate ligands as shown by the structural studies of the corresponding $\mathrm{Rh}(\mathrm{I})$-complex 12. X-ray analysis, and dynamic NMR studies, demonstrated that there is an efficient stereochemical control of the sulfur configuration upon coordination to the rhodium, both in solution and in solid state. The prepared ligands were evaluated in two asymmetric reactions, namely the $\operatorname{Pd}(0)$-catalyzed allylic alkylation, and the $\mathrm{Rh}(\mathrm{I})$-catalyzed hydrogenation of enamides. In both cases the final products were obtained with low ees and moderate yields. Nevertheless, the synthetic simplicity of the synthetic route, associated with the high stereocontrol of the stereogenic sulfur atom, make us optimistic about the behavior of the new ligands in other metal catalyzed asymmetric transformations. 


\section{Experimental Section}

General Methods. All reactions were run under an atmosphere of dry argon using oven-dried glassware and freshly distilled and dried solvents. THF and diethyl ether were distilled from sodium benzophenone ketyl. Dichloromethane was distilled from calcium hydride. TLC was performed on Silica Gel GF254 (Merck) with detection by charring with phosphomolybdic $\mathrm{acid} / \mathrm{EtOH}$. For flash chromatography, silica Gel (Merck 230-400 mesh) was used. Columns were eluted with positive air pressure. Chromatographic eluents are given as volume to volume ratios (v/v). NMR spectra were recorded with a Bruker AMX500 (1H, $500 \mathrm{MHz})$ and Bruker Avance DRX500 $(1 \mathrm{H}, 500 \mathrm{MHz})$ spectrometers. Chemical shifts are reported in ppm, and coupling constants are reported in Hz. Routine spectra were referenced to the residual proton or carbon signals of the solvent. High-resolution mass spectra were recorded on a Kratos MS80RFA 241-MC apparatus. Optical rotations were determined with a Perkin-Elmer 341 polarimeter. 1,2,3,4,5-Penta- $O$-acetyl- $\beta$-D-glucopyranose 1, was purchased from Aldrich.

\section{terc-Butyl 2,3,4,6-tetra- $O$-acetyl-1-thio- $\beta$-D-glucopyranoside, 2}

To a $1 \mathrm{M}$ solution of $\beta$-D-glucose pentaacetate $1(5 \mathrm{~g}, 12.8 \mathrm{mmol})$ in methylene chloride was added tert-butanethiol (1.1 equiv.) followed by boron trifluoride etherate ( 4 equiv.) at $0^{\circ} \mathrm{C}$. The reaction was followed by TLC and stopped once the starting material consumed (usually 0.5 to 1h) by addition of saturated aqueous sodium bicarbonate $\left(\mathrm{NaHCO}_{3}\right)$. The aqueous layer was extracted three times with methylene chloride, and the combined organic layers washed with brine and dried over sodium sulfate. After concentration under vacuum, the crude mixture was purified by column chromatography (EtOAc: Hexanes, 2:3), affording 2 as a white solid (3.77 g, 72\%). m.p. $146-148^{\circ} \mathrm{C}$. $\left(\mathrm{R}_{\mathrm{f}}: 0.3\right.$, EtOAc : Hexanes, $\left.2: 3\right) .[\alpha]_{\mathrm{D}}=+2.9$ (c. $\left.1.0, \mathrm{CHCl}_{3}\right) .{ }^{1} \mathrm{H}$ NMR $\left(500 \mathrm{MHz}, \mathrm{CDCl}_{3}\right) \delta: 5,23(\mathrm{t}, 1 \mathrm{H}, J=9.3 \mathrm{~Hz}$ ), $5.01(\mathrm{t}, 1 \mathrm{H}, J=9.9 \mathrm{~Hz}), 4.92(\mathrm{t}, 1 \mathrm{H}, J=10.1$ $\mathrm{Hz}), 4.61(\mathrm{~d}, 1 \mathrm{H}, J=10.2 \mathrm{~Hz}), 4.17(\mathrm{dd}, 1 \mathrm{H}, J=6.1,12.2 \mathrm{~Hz}), 4.09(\mathrm{dd}, 1 \mathrm{H}, J=2.4,12.2 \mathrm{~Hz})$, 3.72-3.68 (m, 1H), $2.04(\mathrm{~s}, 3 \mathrm{H}), 2.02(\mathrm{~s}, 3 \mathrm{H}), 2.01(\mathrm{~s}, 3 \mathrm{H}), 1.99(\mathrm{~s}, 3 \mathrm{H}), 1.34(\mathrm{~s}, 9 \mathrm{H}) .{ }^{13} \mathrm{C} \mathrm{NMR}$ $\left(125 \mathrm{MHz}, \mathrm{CDCl}_{3}\right) \delta: 170.5,170.1,169.3,169.2,82.2,75.5,73.9,70.1,68.5,62.5,44.2,31.3$, 20.7, 20.6, 20.5. Anal. Calcd. for $\mathrm{C}_{18} \mathrm{H}_{28} \mathrm{O}_{9} \mathrm{~S}: \mathrm{C}, 51.42 \%$, H, 6.70\%. Found: $\mathrm{C}, 51.64 \%$, H, $6.71 \%$.

\section{terc-Butyl 1-thio- $\beta$-D-glucopyranoside, 3}

To a $0.1 \mathrm{M}$ suspension of $2(4.75 \mathrm{~g}, 18.8 \mathrm{mmol})$ in dry methanol was added a catalytic amount of freshly prepared $1 \mathrm{M}$ solution of $\mathrm{MeONa}$ in $\mathrm{MeOH}$ ( 0.1 equiv.). The solution was stirred at room temperature until total consumption of the starting material, then neutralized with acidic resin (Amberlyst IR 120), filtered and evaporated affording 3 as a white solid (97\%). m.p. $114-117^{\circ} \mathrm{C}$. $[\alpha]_{\mathrm{D}}=-47.4\left(\right.$ c. $\left.15.5, \mathrm{CHCl}_{3}\right) .{ }^{1} \mathrm{H} \mathrm{NMR}\left(500 \mathrm{MHz}, \mathrm{CDCl}_{3}\right) \delta: 4.49(\mathrm{~d}, 1 \mathrm{H}, J=9.9 \mathrm{~Hz}), 3.81(\mathrm{dd}$, $1 \mathrm{H}, J=5.3,12.1 \mathrm{~Hz}), 3.70(\mathrm{t}, 1 \mathrm{H}, J=8.5), 3.34-3.25(\mathrm{~m}, 2 \mathrm{H}), 3.11(\mathrm{dt}, 1 \mathrm{H}, J=8.4,1.0 \mathrm{~Hz})$, $1.38(\mathrm{~s}, 9 \mathrm{H}) .{ }^{13} \mathrm{C} \mathrm{NMR}\left(125 \mathrm{MHz}, \mathrm{CDCl}_{3}\right) \delta: 84.3,80.1,78.3,72.9,70.0,61.5,43.3,30.8$. Anal. Calcd. for $\mathrm{C}_{10} \mathrm{H}_{20} \mathrm{O}_{5} \mathrm{~S}: \mathrm{C}, 47.60 \%, \mathrm{H}, 7.99 \%$. Found: C, $46.82 \%, \mathrm{H}, 7.88 \%$. 


\section{tert-Butyl 4,6- $O$-benzylidene-1-thio- $\beta$-D-glucopyranoside (4)}

To a solution of $3(2.75 \mathrm{~g}, 10.9 \mathrm{mmol})$ in DMF was added benzaldehyde dimethyl acetal $(1.99 \mathrm{~g}$, $13.1 \mathrm{mmol}$ ) followed by catalytic amount of $p$-toluenesulfonic acid. The mixture was stirred at $50{ }^{\circ} \mathrm{C}$ for $2 \mathrm{hrs}$, and then the DMF was evaporated under vacuum. The crude mixture obtained was purified by column chromatography (EtOAc : Hexanes, 1:2) affording 3 (3.3g, 9.7mmol, 98\%) as a white solid. M.p.: $65-70{ }^{\circ} \mathrm{C}$. $\left(\mathrm{R}_{\mathrm{f}}: 0.28\right.$, EtOAc : Hexanes, 2:3). $[\alpha]_{\mathrm{D}}=-47.6$ (c. 10.7 , $\left.\mathrm{CHCl}_{3}\right) .{ }^{1} \mathrm{H}$ NMR $\left(500 \mathrm{MHz}, \mathrm{CDCl}_{3}\right) \delta: 7.49(\mathrm{~m}, 2 \mathrm{H}), 7.36(\mathrm{~m}, 3 \mathrm{H}), 4.57(\mathrm{~d}, 1 \mathrm{H}, J=9.8 \mathrm{~Hz})$, 4.31-4.28 (m, 1H), $3.85(\mathrm{t}, 1 \mathrm{H}, J=8.7 \mathrm{~Hz}), 3.77(\mathrm{t}, 1 \mathrm{H}, J=10.0 \mathrm{~Hz}), 3.59-3.50(\mathrm{~m}, 2 \mathrm{H}), 3.42(\mathrm{t}$, $1 \mathrm{H}, J=8.6 \mathrm{~Hz}), 1.40(\mathrm{~s}, 9 \mathrm{H}) .{ }^{13} \mathrm{C} \mathrm{NMR}(125 \mathrm{MHz}, \mathrm{CDCl3}) \delta: 137.1,129.1,128.1,126.4,101.9$, 84.9, 80.3, 74.5, 73.3, 70.3, 68.7, 44.6, 31.7. HRMS Calcd. for $\mathrm{C}_{17} \mathrm{H}_{24} \mathrm{O}_{5} \mathrm{~S}: 340,1344[\mathrm{M}]^{+}$. Found: $340.1361(5.1 \mathrm{ppm})$.

\section{tert-Butyl 4,6- $O$-benzylidene-2,3-di- $O$-methanesulfonyl-1-thio- $\beta$-D-glucopyranoside (5)}

To a solution of $4(3.1 \mathrm{~g}, 9.1$ mmoles $)$ in pyridine $(20 \mathrm{~mL})$ was added at $0^{\circ} \mathrm{C}$ methanesulfonyl chloride $(3.13 \mathrm{~g}, 27.4 \mathrm{mmol})$. After stirring at room temperature for $24 \mathrm{hrs}$, the reaction was stopped by addition of water, extracted with methylene chloride, and the organic layer dried under $\mathrm{Na}_{2} \mathrm{SO}_{4}$. After evaporation of the solvent, the crude solid was recrystallized with acetone/methanol, affording $4(3.5 \mathrm{~g}, 7.1 \mathrm{mmol}, 77 \%)$ as a white solid. m.p.: 101-104 ${ }^{\circ} \mathrm{C}$. ( $\mathrm{R}_{\mathrm{f}}$ : 0.5, EtOAc : Hexanes, $2: 3)$. $[\alpha]_{\mathrm{D}}=+27.2$ (c. 10.6, $\left.\mathrm{CHCl}_{3}\right)$. ${ }^{1} \mathrm{H}$ NMR $\left(500 \mathrm{MHz}, \mathrm{CDCl}_{3}\right) \delta: 7.46$ $(\mathrm{m}, 2 \mathrm{H}), 7.37(\mathrm{~m}, 3 \mathrm{H}), 5.55(\mathrm{~s}, 1 \mathrm{H}), 4.93(\mathrm{t}, 1 \mathrm{H}, J=8.8 \mathrm{~Hz}), 4.72(\mathrm{~d}, 1 \mathrm{H}, J=9.9 \mathrm{~Hz}), 4.64(\mathrm{t}$, $1 \mathrm{H}, J=8.7 \mathrm{~Hz}), 4.37-4.34(\mathrm{~m}, 1 \mathrm{H}), 3.80-3.74\left(\mathrm{~m}, 2 \mathrm{H}, \mathrm{H}-6^{\prime}\right), 3.59-3.55(\mathrm{~m}, 1 \mathrm{H}), 3.23(\mathrm{~s}, 3 \mathrm{H})$, $3.02(\mathrm{~s}, 1 \mathrm{H}), 1.39(\mathrm{~s}, 9 \mathrm{H}) .{ }^{13} \mathrm{C} \mathrm{NMR}\left(125 \mathrm{MHz}, \mathrm{CDCl}_{3}\right) \delta: 136.2,129.5,128.5,126.1,101.8$, 83.3, 80.6, 78.3, 77.6, 70.2, 68.4, 45.2, 40.4, 39.3, 31.4 .

tert-Butyl 4,6- $O$-benzylidene-2,3-anhydro-1-thio- $\beta$-D-allo- and manopyranosides, 6 and 7. To a solution of $5(3.39 \mathrm{~g}, 6.8 \mathrm{mmol})$ in a $2: 1$ mixture $\mathrm{CH}_{2} \mathrm{Cl}_{2}: \mathrm{MeOH}(30 \mathrm{~mL})$ was added $\mathrm{MeONa}(2.95 \mathrm{~g}, 54.7 \mathrm{mmoles})$ at room temperature. After stirring over night, the reaction was stopped by addition of water $(30 \mathrm{~mL})$, and the aqueous phase extracted with $\mathrm{CH}_{2} \mathrm{Cl}_{2}$, and dried over anhydrous $\mathrm{Na}_{2} \mathrm{SO}_{4}$. After evaporation of the solvent, the crude product was purified by column chromatography (EtOAc : Hexanes, $1: 9)$ affording the desired epoxides (81\%) 6 and 7 in a $3: 2$ ratio.

tert-Butyl 2,3-anhydro-4,6- $\boldsymbol{O}$-benzylidene-1-thio- $\boldsymbol{\beta}$-D-allopyranoside $(6)$. ( $\mathrm{R}_{\mathrm{f}}: 0.8$, EtOAc : Hexanes, $2: 3)$. $[\alpha]_{\mathrm{D}}{ }^{20}:-25.0$ (c. 6.9, $\left.\mathrm{CHCl}_{3}\right) .{ }^{1} \mathrm{H}-\mathrm{NMR}\left(500 \mathrm{MHz}, \mathrm{CDCl}_{3}\right) \delta: 7.51(\mathrm{~m}, 2 \mathrm{H}), 7.37$ $(\mathrm{m}, 3 \mathrm{H}), 5.56(\mathrm{~s}, 1 \mathrm{H}), 5.29(\mathrm{~s}, 1 \mathrm{H}), 4.22-4.19(\mathrm{~m}, 1 \mathrm{H}), 4.10(\mathrm{~d}, 1 \mathrm{H}, J=9.0 \mathrm{~Hz}), 3.87-3.83(\mathrm{~m}$, $1 \mathrm{H}), 3.72(\mathrm{t}, 1 \mathrm{H}, J=10.0 \mathrm{~Hz}), 3.56(\mathrm{~d}, 1 \mathrm{H}, J=4.0 \mathrm{~Hz}), 3.5(\mathrm{~d}, 1 \mathrm{H}, J=4.0 \mathrm{~Hz}), 1.4(\mathrm{~s}, 9 \mathrm{H}) .{ }^{13} \mathrm{C}-$ NMR (125 MHz, $\left.\mathrm{CDCl}_{3}\right) \delta: 137.1,129.3,128.3,126.3,102.7,77.5,68.9,64.3,57.2,51,8,44.9$. Anal. Calcd. for $\mathrm{C}_{17} \mathrm{H}_{22} \mathrm{O}_{4} \mathrm{~S}$ : C, 63.33\%; H, 6.88\%. Found: C: 63.05\%. H: 6.96\%.

tert-Butyl 2,3-anhydro-4,6-O-benzylidene-1-thio- $\boldsymbol{\beta}$-D-manopyranoside (7). Solid. m.p. : 128 $132^{\circ} \mathrm{C} .\left(\mathrm{R}_{\mathrm{f}}: 0.8\right.$, EtOAc : Hexanes, $\left.2: 3\right)[\alpha]_{\mathrm{D}}{ }^{20}:-2,2\left(\mathrm{c} 1.1, \mathrm{CHCl}_{3}\right) .{ }^{1} \mathrm{H}-\mathrm{NMR}(500 \mathrm{MHz}$,

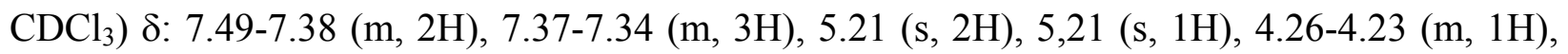
3.78-3.73 (m, 2H), $3.5(\mathrm{~d}, 1 \mathrm{H}, J=3.6 \mathrm{~Hz}), 3.37-3.3(\mathrm{~m}, 1 \mathrm{H}), 3.29(\mathrm{~d}, 1 \mathrm{H}, J=0.8 \mathrm{~Hz}), 1.41$ (s, 9H). ${ }^{13} \mathrm{C}-\mathrm{NMR}\left(125 \mathrm{MHz}, \mathrm{CDCl}_{3}\right) \delta: 137.2,129.2,128.3,126.2,102.3,78.5,74.6,70.4,69.3$, 
55.4, 53.1, 44.0, 31.6. HRMS Calcd. for: $\mathrm{C}_{17} \mathrm{H}_{23} \mathrm{O}_{4} \mathrm{~S}: 323.1317$ [M+1] $]^{+}$. Found: 323.1311 (-1.9 ppm).

tert-Butyl 4,6-O-benzylidene-2-deoxy-2-diphenylphosphino-1-thio- $\boldsymbol{\beta}$-D-altropyranoside (8). To a solution of $6(575 \mathrm{mg}, 1.8 \mathrm{mmol})$ in a $1: 1$ mixture of THF : DMF $(8 \mathrm{~mL})$ at $-10^{\circ} \mathrm{C}$ was added a freshly prepared $\left(\mathrm{PPh}_{2} \mathrm{H}+\mathrm{BuLi}\right.$ in THF) and titrated $0.6 \mathrm{M}$ diphenylphosphinyl lithium solution (6 mL, $3.5 \mathrm{mmol})$. After $1 \mathrm{hr}, \mathrm{NH}_{4} \mathrm{Cl}(200 \mathrm{mg}, 3.7 \mathrm{mmol})$ was added and stirring was continued for $30 \mathrm{~min}$ more before evaporating the solvent. After coevaporation with toluene, the crude mixture was purified by column chromatography (EtOAc : Hexanes, $1: 6$ ), affording 8 $(708 \mathrm{mg}, 78 \%)$ as a white solid. $[\alpha]_{\mathrm{D}}{ }^{20}:+13.9\left(\right.$ c. $\left.0.6, \mathrm{CHCl}_{3}\right) .{ }^{1} \mathrm{H}-\mathrm{NMR}\left(500 \mathrm{MHz}, \mathrm{CDCl}_{3}\right) \delta$ : 7.55-7.51 (m, 5H), 7.38-7.28 (m, 10H), $5.6(\mathrm{dd}, 1 \mathrm{H}, J=3.4,24.4 \mathrm{~Hz}), 4.93(\mathrm{~s}, 1 \mathrm{H}), 4.19-4.10$ (m, 2H), 3.90-3.85 (m, 1H), $3.35(\mathrm{t}, 1 \mathrm{H}, J=10.2 \mathrm{~Hz}), 3.08(\mathrm{dd}, 1 \mathrm{H}, J=2.9,5.3 \mathrm{~Hz}), 2.5$ (bs, $1 \mathrm{H}), 2.40(\mathrm{dd}, 1 \mathrm{H}, J=2.9,9.6 \mathrm{~Hz}), 1.38(\mathrm{~s}, 9 \mathrm{H}) .{ }^{13} \mathrm{C}-\mathrm{NMR}\left(125 \mathrm{MHz}, \mathrm{CDCl}_{3}\right) \delta: 137.1,136.9$ (d, $J=19.7 \mathrm{~Hz}), 135.8$ (d, $J=10.9 \mathrm{~Hz}), 135.3$ (d, $J=21.9 \mathrm{~Hz}), 132.2$ (d, $J=18.3 \mathrm{~Hz}), 129.4$ (d, $J=51.4 \mathrm{~Hz}$ ), 128.7, 128.6, 128.5, 128.4, 128.3, 128.2, 126.1, 101.8, 81.0 (d, $J=14.5 \mathrm{~Hz}), 76.3$, 69.3, 68.3 (d, $J=1.4 \mathrm{~Hz}), 67.6,44.81$ (d, $J=22.3 \mathrm{~Hz}), 31.6 .{ }^{31} \mathrm{P}-\mathrm{NMR}(121.4 \mathrm{MHz}) \delta:-19.1$ ppm.

tert-Butyl 3-O-acetyl-4,6- $O$-benzylidene-2-deoxy-2-diphenylphosphino-1-thio- $\beta$-Daltropyranoside (9). To a solution of $8(1.17 \mathrm{~g}, 2.3 \mathrm{mmol})$ in pyridine $(2 \mathrm{~mL})$, at room temperature, was added acetic anhydride $(355 \mathrm{mg}, 3.47 \mathrm{mmol})$. After $2 \mathrm{hrs}$, the solvent was evaporated affording $9(82 \%)$ as a white solid. m.p: $141-143^{\circ} \mathrm{C} .[\alpha]_{\mathrm{D}}{ }^{20}:-29.3$ (c.0.25, $\left.\mathrm{CHCl}_{3}\right)$, ${ }^{1} \mathrm{H}-\mathrm{NMR}\left(500 \mathrm{MHz}, \mathrm{CDCl}_{3}\right) \delta: 7.68-7.64(\mathrm{~m}, 5 \mathrm{H}), 7.42-7.34(\mathrm{~m}, 10 \mathrm{H}), 5.45(\mathrm{dd}, 1 \mathrm{H}, J=2.9$, $30.0 \mathrm{~Hz}), 5.38-5.36(\mathrm{~m}, 1 \mathrm{H}), 4.95(\mathrm{~s}, 1 \mathrm{H}), 4.20(\mathrm{dd}, 1 \mathrm{H}, J=5.0,10.0 \mathrm{~Hz}), 3.91(\mathrm{td}, 1 \mathrm{H}, J=5.0$, $10.0 \mathrm{~Hz}), 3.57(\mathrm{t}, 1 \mathrm{H}, J=10.5 \mathrm{~Hz}), 3.14(\mathrm{dd}, 1 \mathrm{H}, J=2.7,5.7 \mathrm{~Hz}), 2.86(\mathrm{dd}, 1 \mathrm{H}, J=2.9,9.6 \mathrm{~Hz})$, $2.15(\mathrm{~s}, 3 \mathrm{H}), 1.38(\mathrm{~s}, 9 \mathrm{H}) .{ }^{13} \mathrm{C}-\mathrm{NMR}\left(125 \mathrm{MHz}, \mathrm{CDCl}_{3}\right) \delta: 170.0,137.2,136.1(\mathrm{~d}, J=10.6 \mathrm{~Hz})$, $135.9(\mathrm{~d}, J=10.5 \mathrm{~Hz}), 135.6(\mathrm{~d}, J=22.8 \mathrm{~Hz}), 132.7(\mathrm{~d}, J=19.3 \mathrm{~Hz}), 129.9,128.9,128.7,128.7$, 128.6, 128.5, 128.3, 128.2, 101.6, 81.1(d, $J=16.1 \mathrm{~Hz}), 74.4,70.6,69.2,68.3,44.8,44.5$ (d, $J=25.6 \mathrm{~Hz}), 31.5,21.2 .{ }^{31} \mathrm{P}-\mathrm{NMR}\left(121.4 \mathrm{MHz}, \mathrm{CDCl}_{3}\right) \delta$ : -19.1. Anal. Calcd. for $\mathrm{C}_{31} \mathrm{H}_{35} \mathrm{O}_{5} \mathrm{PS}$ : C, 67.62\%; H, 6.41\%. Found: C, 67.20\%, H, 6.19\%.

\section{Preparation of $\mathrm{Rh}(\mathrm{I})$ complex 12}

A solution of ligand $9(31 \mathrm{mg}, 0.05 \mathrm{mmol})$ in dry and deoxygenated methylene chloride $(1 \mathrm{~mL})$ was added via canula over a slurry of $\left[\mathrm{Rh}(\mathrm{COD})_{2}\right] \mathrm{SbF}_{6}$ (1 equiv.) in methylene chloride $(1 \mathrm{~mL})$. After $1 \mathrm{hr}$, the $2 / 3$ of the solvent was evaporated, and $1 \mathrm{~mL}$ of THF was added, followed by $8 \mathrm{~mL}$ of hexanes in order to precipitate the complex. Alter filtration, the complex was obtained in quantitative yield as an orange solid. $[\alpha]_{\mathrm{D}}{ }^{20}:+29.4$ (c. $\left.0.3, \mathrm{MeOH}\right) .{ }^{1} \mathrm{H}-\mathrm{NMR}\left(500 \mathrm{MHz}, \mathrm{CDCl}_{3}\right)$ $\delta: ~ 8.15-7.10(\mathrm{~m}, 15 \mathrm{H}), 6.09-5.92\left(\mathrm{~m}, 2 \mathrm{H}, \mathrm{C}_{8} \mathrm{H}_{12}\right), 5.83(\mathrm{~d}, 1 \mathrm{H}, J=38.9 \mathrm{~Hz}), 5.49(\mathrm{~s}, 1 \mathrm{H}), 4.66(\mathrm{~s}$, $1 \mathrm{H}), 4.25-4.29(\mathrm{~m}, 1 \mathrm{H}), 4.07(\mathrm{dd}, 1 \mathrm{H}, J=4.9,10.3 \mathrm{~Hz}), 3.84-3.79(\mathrm{~m}, 1 \mathrm{H}), 3.37-3.36(\mathrm{~m}, 1 \mathrm{H})$, 3.19-3.17 (m, 1H), $2.82(\mathrm{t}, 1 \mathrm{H}, J=10.2 \mathrm{~Hz}), 2.54-2.36(\mathrm{~m}, 4 \mathrm{H}), 2.21$ (dd, $1 \mathrm{H}, J=3.2,9.7 \mathrm{~Hz})$, $2.19(\mathrm{~s}, 3 \mathrm{H}), 2.08-2.04(\mathrm{~m}, 1 \mathrm{H}), 1.96-1.90(\mathrm{~m}, 1 \mathrm{H}), 1.67(\mathrm{~s}, 9 \mathrm{H}) .{ }^{13} \mathrm{C}-\mathrm{NMR}\left(125 \mathrm{MHz}, \mathrm{CDCl}_{3}\right)$ $\delta: 169.9,136.9,136.4,133.4,132.1,131.2(\mathrm{~d}, J=8.5 \mathrm{~Hz}), 129.9$ (d, $J=9.8 \mathrm{~Hz}), 129.6,129.4$ (d, 
$J=10.0 \mathrm{~Hz}), 129.2,128.2,125.8,124.5,124.1,103.4(\mathrm{~d}, J=9.0 \mathrm{~Hz}), 102.7,101.8,88.9(\mathrm{~d}, J=$ $10.2 \mathrm{~Hz}), 83.0(\mathrm{~d}, J=6.5 \mathrm{~Hz}), 82.7$ (d, $J=10.0 \mathrm{~Hz}), 73.5,69.1,68.5,65.9,59.7,46.0$ (d, $J=18.1$ $\mathrm{Hz}), 32.9,31.6,30.4,29.6,28.1,20.8 .{ }^{31} \mathrm{P}-\mathrm{NMR}\left(121.4 \mathrm{MHz}, \mathrm{CDCl}_{3}\right) \delta: 58.5(\mathrm{~d}, J=121 \mathrm{~Hz})$.

\section{General Procedure for the allylic alkylation with dimethyl malonate}

$(R, E)$-Methyl 2-carbomethoxy-3,5-diphenylpent-4-enoate (11). To a solution of the ligand (4.3 mol\%) in dry deoxygenated methylene chloride $(0.5 \mathrm{~mL})$, was added under argon $\left[\left(\mathrm{C}_{3} \mathrm{H}_{5}\right) \mathrm{PdCl}\right]_{2}$ $(1.5 \mathrm{~mol} \%)$. The reaction mixture was stirred for $1 \mathrm{~h}$ at room temperature, then a catalytic amount of KOAc $(0.5 \mathrm{mg})$ was added, followed by BSA ( 3 mol equiv.) and a disolution of 1,3-diphenyl2-propenyl acetate 10 ( 1 mol equiv.) in dry deoxygenated methylene chloride $(0.7 \mathrm{~mL})$. The temperature was then adjusted to the desired one (see Table 1), and dimethyl malonate (3 equiv.) was added. After $24 \mathrm{hrs}$, the solvent was evaporated and the residue purified by column chromatography, affording the desired product $\mathbf{1 1}$ as a viscous oil which solidify on standing.

${ }^{1} \mathrm{H}$ NMR $\left(500 \mathrm{MHz}, \mathrm{CDCl}_{3}\right) \delta: 7.36-7.19(\mathrm{~m}, 10 \mathrm{H}), 6.49(\mathrm{~d}, 1 \mathrm{H}, J=15.7 \mathrm{~Hz}), 6.34(\mathrm{dd}, 1 \mathrm{H}, J=$ 15.7, $8.6 \mathrm{~Hz}), 4.28(\mathrm{dd}, 1 \mathrm{H}, J=10.9,8.6 \mathrm{~Hz}), 3.97(\mathrm{~d}, 1 \mathrm{H}, J=10.9 \mathrm{~Hz}), 3.71(\mathrm{~s}, 3 \mathrm{H}), 3.52(\mathrm{~s}$, $3 \mathrm{H})$. HRMS Calcd. for $\mathrm{C}_{15} \mathrm{H}_{14} \mathrm{ONa}: 210.1045$ [M+Na] $]^{+}$, Found: 210.1054 (-4.6 ppm).

The enantiomeric excess was determined by chiral HPLC using a Chiralpack AD column ( $1 \mathrm{~mL} /$ $\min ,{ }^{i} \mathrm{PrOH}$ : Hexanes, $\left.5: 95,30^{\circ} \mathrm{C}\right), t_{R}=14.2 \mathrm{~min}(\mathbf{2 0 R})$ and $t_{R}=19.5 \mathrm{~min}(\mathbf{2 0 S})$. The absolute configuration of the product was determined by comparison of the optical rotation with that reported in the literature. ${ }^{23}$

\section{General Procedure for the hydrogenation of methyl acetamido cinnamate}

A mixture of methyl acetamido cinnamate $\mathbf{1 3}(50 \mathrm{mg})$ and complex $12(1 \mathrm{~mol} \%)$ in methylene chloride $(2 \mathrm{~mL})$ were charged in a hydrogenation reactor. After 2 vacuum / argon cycles, the reactor was filled with hydrogen at the desired pressure, and stirred at room temperature for 24 hrs. Then the reaction mixture was filtered over celite, the solvent evaporated, and the crude mixture analyzed by NMR in order to determine the total conversión of starting material. The enantiomeric excess was determined by chiral HPLC using a Chiralcel OJ column $(1 \mathrm{~mL} / \mathrm{min}, i-$ $\mathrm{PrOH}$ : Hexanes, $\left.3: 97,30^{\circ} \mathrm{C}\right), t_{R}=17.0 \mathrm{~min}(\mathbf{1 4 R})$ and $t_{R}=25.3 \mathrm{~min}(\mathbf{1 4 S})$. The configuration of the major isomer was determined by comparing the sign of the optical rotation with that reported in the literature. ${ }^{24}$

\section{Acknowledgement}

We thank the Dirección General de Investigación Científica y Técnica (grant No. CTQ200615515-CO2-01 and CTQ2007-61185), the Junta de Andalucía (grant P06-FQM-01852 and P07FQM-2774), la Fundación Ramón Areces for financial support, and Mr M. Rudkowski for performing preliminary experimental work. 


\section{References and Notes}

1. Stinson, S. C. Chem. Eng. News 2001, 79, 45. (b) A. M. Rouhi. Chem Eng. News 2003, 81, 45.

2. See 2001 Nobel Lectures. Angew. Chem. Int. Ed. 2002, 41, 998.

3. Recently 2 Issues of the Proceedings of the National Academy of Sciences of the USA were dedicated to the Special Feature of asymmetric catalysis, see: PNAS no. 15, April 13, 2004, and PNAS no. 16, April 20, 2004.

4. Chiral Auxiliaries and Ligands in Asymmetric Synthesis; J. Seyden-Penne, Ed.; Wiley Interscience: New York, 1995; Comprehensive Asymmetric Catalysis, Vol. I-III; Jacobsen, E. N.; Pfaltz, A., Yamamoto, H., Springer: Berlin, 1999.

5. Blaser, H. -U. Chem. Commun. 2003, 293.

6. (a) Dieguez, M., Pàmies, O., Claver, C. Chem Rev. 2004, 104, 3189. (b) Steiborn, D., Junicke, H. Chem. Rev. 2000, 100, 4283. (c) Rajanbabu, T. V., Casalnuovo, A. L., Ayers, T. A. In Advances in Catalytic Processes, Doyle, M. P., Ed.; JAI Press: Greenwich, CT, 1998, Vol. 2. p.1.

7. Fernández, I., Khiar, N. Chem. Rev. 2003, 103, 3651; (b) Khiar, N., Fernández, I., Alcudia, F. Tetrahedron Lett. 1993, 34, 123. (c) Khiar, N., Alcudia, F., Espartero, J. -L., Rodríguez, L., Fernández, I. J. Am. Chem. Soc. 2000, 122, 7598. (d) Khiar, N., Araújo, C. S., Alcudia, F., Fernández, I. J. Org. Chem. 2002, 67, 345.

8. Khiar, N., Araújo, C. S., Alvarez, E., Fernández, I. Tetrahedron Lett. 2003, 44, 3401. (b) Khiar, N., Suárez, B., Valdivia, V., Fernández, I. Synlett 2005, 2963. (c) Khiar, N., Araújo, C. S., Suárez, B., Fernández, I., Eur. J. Org. Chem. 2006, 1685. (d) Khiar, N., Suárez, B., Fernández, I. Inorg. Chim. Acta 2006, 359, 3048

9. Some representative P/S ligands: (a) Molander, G., Burke, J., Carrol, P. J. J. Org. Chem. 2004, 69, 8062, (b) Mancheño, O. G., Gomez Arrayas, R., Carretero, J. C. J. Am Chem Soc. 2004, 126, 456. (c) Evans, D. A., Campos, K. R., Tedrow, J. S., Michael, F. E., Gagne, M. R. J. Am Chem Soc. 2000, 122, 7905. (d) Yan, Y. Y., Rajanbabu, T. V. Org. Lett. 2000, 2, 199. (e) Albinati, A., Pregosin, P. S., Wick, K. Organometallics, 1996, 15, 2419.

10. (a) Knowles, W. S., Sabacky, M. J., Vineyard, B. D., Weinkauff, D. J. J. Am. Chem Soc. 1975, 97, 2567. (b) Knowles, W. S. Angew. Chem. Int. Ed. Engl. 2002, 41, 1999.

11. (a) Abel, E., Bhargava, S. K., Orrell, K. G. Prog. Inorg. Chem. 1984, 32, 1. (b) Abel, E., Dormer, J., Ellis, D., Orrell, K. G., Sik, V., Hursthouse, M. B., Mazid, M. A. J. Chem. Soc., Dalton Trans. 1992, 1073.

12. For an efficient steric control of the sulfur metal bond see: (a) Evans, D. A., Michael, F. E., Tedrow, J. S., Campos, K. R. J. Am. Chem. Soc. 2003, 125, 3538. and for a stereoselectronic control see: (b) Khiar, N., Araújo, C. S., Suárez, B., Álvarez, E., Fernández, I. Chem. Commun. 2004, 44.

13. (a) Castillon, S., Claver, C., Diaz, Y. Chem. Soc. Rev. 2005, 34, 702. (b) Diéguez, M., Pàmies, O., Ruiz, A., Diaz, Y., Castillon, S., Claver, C. Coord. Chem. Rev. 2004, 248, 1759. 
14. (a) Shi, J-C., Chen, L-J., Huang, X-Y., Wu, D-X., Kang, B-S. J. Organometal. Chem. 1997, 535, 17. (b) Shi, J-C., Yueng, C-H., Wu, D-X., Liu, Q-T., Kang, B-S. Organometallics 1999, $18,3796$.

15. Crystal data for 6: $\mathrm{C}_{17.33} \mathrm{H}_{22.33} \mathrm{ClO} \mathrm{S}\left[\mathrm{C}_{17} \mathrm{H}_{22} \mathrm{O}_{4} \mathrm{~S}, 0.33\left(\mathrm{CHCl}_{3}\right)\right], M_{w}=362.20$, a single crystal of suitable size, green prism $\left(0.19 \times 0.14 \times 0.10 \mathrm{~mm}^{3}\right)$ from $\mathrm{CHCl}_{3}$, coated with dry perfluoropolyether was mounted on a glass fiber and fixed in a cold nitrogen stream, 100(2) $\mathrm{K}$, to the goniometer head. Triclinic, space group $P 1, a=5.4233(4) \AA, b=11.0184(9) \AA, c$ $=22.3082(19) \AA, \alpha=88.851(2)^{\circ}, \beta=85.700(3)^{\circ}, \gamma=89.726(3)^{\circ}, V=1329.02(18) \AA^{3}, Z=$ $3, \rho_{\text {calcd }}=1.358 \mathrm{gcm}^{-3}, \lambda\left(\mathrm{Mo} \mathrm{K}_{\alpha 1}\right)=0.71073 \AA, \mathrm{F}(000)=574, \mu=0.351 \mathrm{~mm}^{-1}$. CCDC 654458 contains the supplementary crystallographic data for this paper. These data can be obtained free of charge from the Cambridge Crystallographic Data Centre via www.ccdc.cam.ac.uk/data request/cif.

16. Fürst, A., Plattner, P. A. Helv. Chim. Acta 1949, 32, 275.

17. (a) Pfaltz, A., Lautens, M. In Comprehensive Asymmetric Catalysis, Volumes II, Jacobsen, E. N., Pfaltz, A., Yamamoto, H., (Eds.), Springer: New York, 1999., Chap. 24, p. 834. (b) Trost, B. M. Chem. Rev. 1996, 96, 395. (c) Trost, B. M., Crawley, M. L. Chem. Rev. 2003, 103, 2921.

18. Blaser, H. -U., Pugin, B., Spindler, F., J. Mol Catal. A. 2005, 231, 1.

19. (a) Knowles, W. S., Sabacky, M. J., Vineyard, B. D. J. Chem. Soc., Chem. Commun. 1972, 10. (b) Kagan, H. B., Dang, T. P. J. Am. Chem. Soc. 1972, 94, 6429. (c) Achiwa, K. J. Am. Chem. Soc. 1976, 98, 8265. (d) Fryzuk, M. D., Bosnich, B. J. Am. Chem. Soc. 1977, 99, 6262.

20. Rajanbabu, T. V., Ayers, T. A., Halliday, G. A., You, K. K., Clabrese, J. C. J. Org. Chem. 1997, 62, 6028.

21. Crystal data for 12: $\mathrm{C}_{79} \mathrm{H}_{96} \mathrm{Cl}_{2} \mathrm{~F}_{12} \mathrm{O}_{10} \mathrm{P}_{2} \mathrm{Rh}_{2} \mathrm{~S}_{2} \mathrm{Sb}_{2}$ [2( $\left.\mathrm{C}_{39} \mathrm{H}_{47} \mathrm{O}_{5} \mathrm{PRhS}\right), 2\left(\mathrm{~F}_{6} \mathrm{Sb}\right), \mathrm{CH}_{2} \mathrm{Cl}_{2}$ ], $M_{w}=$ 2079.84 , a single crystal of suitable size, green plate $\left(0.40 \times 0.18 \times 0.16 \mathrm{~mm}^{3}\right)$ from $\mathrm{CH}_{2} \mathrm{Cl}_{2}$ hexane, coated with dry perfluoropolyether was mounted on a glass fiber and fixed in a cold nitrogen stream, $100(2) \mathrm{K}$, to the goniometer head. Monoclinic, space group $P 2_{1}, a=$ 10.2424(12) $\AA, b=19.519(2) \AA, c=21.114(2) \AA, \beta=103.788(4)^{\circ}, V=4099.5(8) \AA^{3}, Z=2$, $\rho_{\text {calcd }}=1.685 \mathrm{gcm}^{-3}, \lambda\left(\mathrm{Mo} \mathrm{K}_{\alpha 1}\right)=0.71073 \AA, \mathrm{F}(000)=2092, \mu=1.287 \mathrm{~mm}^{-1}$. CCDC 654459 contains the supplementary crystallographic data for this paper. These data can be obtained free of charge from The Cambridge Crystallographic Data Centre via www.ccdc.cam.ac.uk/data request/cif.

22. Surprisingly it has been observed before that the sulfur substituents in palladium and rhodium chelate rings have the general tendency to adopt a pseudoaxial position, see for instance ref. 9a, 12a and 12b. See also: Barbaro, P., Currao, A., Herrmann, J., Nesper, R., Pregosin, P., Salzmann, R. Organometallics 1996, 15, 1879.

23. Sprinz, J., Helmchen, G. Tetrahedron Lett. 1993, 34, 1769.

24. Knowles, W. S., Sabacky, M. J. J. Chem. Soc. Chem. Commun. 1968, 1445. 